\title{
PARTICIPATION OF COMMUNITY IN PUBLIC SECTOR SCHOOLS OF KHYBER PAKHTUNKHWA AND PUNJAB REGARDING TEACHING- LEARNING PROCESS: A CASE STUDY OF DIKHAN AND BHAKKAR DISTRICTS
}

\author{
Abdul Hafeez ${ }^{1 *}$, Malik Amer Atta ${ }^{2}$, Khalid Saeed Akbar ${ }^{3}$, Sobia Tabassum ${ }^{4}$, Komal Mehreen $^{5}$ \\ ${ }^{1 *}{ }^{*}$ Sub Divisional Education Officer in Elementary \& Secondary Department, Pakistan; ${ }^{2}$ Assistant Professor, IER, \\ Gomal University, Dera Ismail Khan, Khyber Pakhtunkhwa (KP), Pakistan; ${ }^{3}$ Subject Specialist, in Elementary \& \\ Secondary Education Department, Pakistan; ${ }^{5} \mathrm{Ph}$.D. Scholar, Deptt: of Communication \& Media studies, Gomal \\ University, D.I.Khan Khyber Pakhtunkhwa (KP), Pakistan. \\ Email: ${ }^{1 *}$ hafeezjoya007@gmail.com, ${ }^{2}$ malikamiratta@gmail.com, ${ }^{3}$ khalid_akbar81@yahoo.com, ${ }^{4}$ qantra@ @otmail.com, \\ ${ }^{5}$ komalmehreen21@gmail.com \\ Article History: Received on $15^{\text {th }}$ March 2021, Revised on $29^{\text {th }}$ June 2021, Published on $30^{\text {th }}$ June 2021
}

\begin{abstract}
Purpose of the study: This study was conducted to find the participation rate of the community in the affairs of public sector schools especially in the process of teaching and learning. Comparison of the views of stakeholders as well as their participation rate in two provinces of Pakistan.
\end{abstract}

Methodology: The research was Descriptive and the quantitative method of research was used to find the results. Selfdeveloped questionnaire as a research tool used after validation. Analysis of collected data done through using Statistical Package for Social Sciences (SPSS) version.21.

Main findings: There is a strong participation rate of community found in the affairs of public sector schools especially in the teaching-learning process. All the groups of stakeholders' i.e. Members of PTC/SMC (Chairman-Secretaries) and Non-members of PTC/SMC (Teachers-Parents) were in favor. No significant difference was found in the perception of groups of stakeholders. However, this participation rate is higher in Khyber Pakhtunkhwa than in Punjab.

Application of the study: This study is applicable in the present scenario of Pakistan, which reflects the strength of participation of the community. This study will provide strong evidence of how important the community is and its intervention in children's education. This study will provide a strong basis for policymakers and implementers to design and implement such policies, which help strengthen the community's role in public sector schools.

Novelty/Originality of this study: The results of the study reflect its novelty of research. This research targeted to find the rate of participation and comparison of this rate between two provinces. It will open various gates of research in this field. This research provides a strong basis for different researchers to make comparisons and discuss the reasons against the poor participation rate of community participation and discuss the benefits of a strong rate of participation.

Keywords: Parent Teacher Council, School Management Committee, Community Participation, Teaching-Learning Process, Khyber Pakhtunkhwa, Punjab.

\section{INTRODUCTION}

Participation of the community in school affairs has great capabilities in removing mistrust and distance between schools and people by encouraging transparency of information, the culture of mutual respect by joint efforts in the ways of school's improvement. In this way, they can share their vision, efforts, capabilities, and results. (Clinton \& Hattie, 2013)

Teachers and parents have a close liaison from the beginning for the schooling of children. Parents are required to know the sources through which his/her child can groom rapidly. It has been noticed that parental involvement in poor families reported low and this leads to the deficiencies in academics of students. Low academic conditions reported even that students did not able to speak fluently at their primary areas of study. (Child Trends, 2018)

It was a fact that teachers' and students' coordination causes the improvement in the learning environment. Classroom diversity is a reported challenge for teachers because the students have affiliations with different communities and different social setups. Tense relationships with parents have also a reverse impact on the performance of students. For students, uplifting in academics is the intense need to encourage the participation of parents in every field of life especially in education and schools. (OCED, 2018)

The parental impact of involvement in the education of their children showed that students felt confident and their motivation level is greater than those children whose parental involvement is weak in their schooling. Parental involvement reflects high efficiency in academics of children, the clarity of their perceptions, increase in their autonomous motivation level and learning level. (Fenton et al, 2017)

Recent findings of researches pointed out very clearly that parental interest in the education of children creates a genuine impact and enhances the students' learning. Parent's level of thinking and creativity causes the encouragement of the students about their contribution in matters of school, their experiences, their bad effects, and their solution. Parental 
support the students in contributing all the positive affairs of school, resolution of their issues, achieving their personal goals and targets. (Sikio et al. 2017)

Participation of the Community in the public sector means people's involvement in schools for the betterment of educational institutions. Different countries have different visions but most of them agree that without the participation of the community the improvement in the school sector is not possible (Government of Punjab 2013). For this purpose, the government of Pakistan has given special attention to involving parents of children in the affairs of schools to establish their sense of ownership. The Government of Punjab as well as Khyber Pakhtunkhwa has introduced the concept of School Management Committees and Parent-Teacher Councils at each school level. (Government of Khyber $\underline{\text { Pakhtunkhwa 2011) }}$

The Government of Khyber Pakhtunkhwa has taken a bold step to strengthen the failing condition of academics in public sector schools. In this scenario, the joint efforts of the board of directors of the Elementary Education Foundation, chief minister of KPK become helpful in the process of decision making. Community participation becomes possible in the region in response to their joint efforts and sensitization process regarding this issue. It fulfills the objective of improving elementary education by involving the community, training teachers for enhancing their skills, and developing a proper line of action for Maktab and Madrassa schools. (Government of Khyber Pakhtunkhwa Elementary Education Foundation, 2012)

It is a fact that Khyber Pakhtunkhwa tried his best to increase the rate and interest of community people to strengthen the institution and especially schools.in this connection, the Government has started the program in 1999 titled Education sector reform unit(ESRU). The concept of Parent-Teacher Associations (PTAs) at each level school was introduced and in 2010 this was renamed as Parent-Teacher Councils (PTCs). The powers and authorities of PTCs specified in the main focus were on the improvement of the teaching-learning process and physical conditions of schools ( $\underline{\text { Government of }}$ Khyber Pakhtunkhwa, 2011).

Sender and Sheldon (2009) describe in research that community played a vital role in the overall development of educational institutions. All the activities performed by the school like enhancing the skills of students, increase their motivation level regarding their academics. Due to strong liaison with community members, the administration of educational institutions become stronger and become able to provide quality education.

Golding (2008) discussed in his study that the relationship between parents with school staff plays a pivotal role and is the key factor to get clear directions in the achievement of its goals. In this scenario, a parent-teacher meeting (PTM) is a strong event in which parents and teachers meet with a single agenda on how to improve the academics of children and how the goals achieved are defined by the government.

Bryan (2005) discussed in his study that children are dependent on their parents for everything as well as the teachers. Both the personalities are important for the personality development of children positively or negatively as per available circumstances, therefore the school is the central point that is responsible for the physical, emotional, cognitive, psychological, and economic development of children. This may be responsible for arranging curricular and cocurricular activities by involving community persons.

Annunziata et al (2006) discussed the strong link between children, school, and parents. They also discussed the causes of failure of academic activities of school due to less interest of parents, abusing behaviors' of teachers, negligence of society as well as teachers, emotional blackmailing from the parents, no choice of subjects and harsh behavior of teachers are basic hurdles in the way of the progress of children's academics.

Govinda and Diwan (2005), the participation of the community in curricular and co-curricular activities leads to enhancing the quality of education, removing different hurdles faced by an educational institution. School is performed as the center for society who serves for a quick fulfillment of educational services, solving different issues, strengthens the decision made by the heads of institutes, and enhances courage to the students for ownership of schools.

Smith (2011) discussed that school councils are very supportive of the functioning of schools and it is very common that parents are involved in the affairs of schools for showing their sense of ownership then it will be fruitful in upgrading the academic condition of children studying there. If the communities support the educational institution with the involvement of parents then quality education must not be compromised.

Kwatubana and Makhalemele (2015) reflected in research that some institutions use different techniques for attracting parents regarding the admission of students in schools which are not fruitful in the efficiency of the school. Most of the parents are not interested in the affairs of schools and heads of institutions waste their time inviting parents to discuss students' issues and sometimes they get tired of this practice. It has been observed that if parents are properly visiting the educational institutes rapidly then they will be able to support the institution far from the sack of children. In this regard, it is required the head of the institute may take different measures to involve the parents. Kocayoruk and Simsek (2016) discussed the impact of children's mental and psychological factors on the improvement of their academics. If parents support the schools and are involved in the affairs of schools, their motivational behavior helps to support the academics of children. 
Lomasonf et al (2017) discussed the rate of parental involvement and its impact on the growth of the children. Continuous monitoring and supervision mechanisms played an effective role in the progress of school efficiency. Parents of school children increase the interest and encourage the level of students. Teachers want to do creative work to enhance the progress of students but due to the non-willingness of their parents, they have failed to accomplish their tasks. If parents work with teachers as partners and own their tasks in the personality development of children then there is no hurdle against the progress of students as well as at school. The optimistic behavior of parents causes changes in the way of the progress of the educational institution.

Nasira (2010) described her research in which she discussed the school council's impact and working pattern in five districts of Punjab. The study evaluated that betterment and academic progress are the key essence of the progress of schools. In some districts, these councils cannot play a vital role due to the non-serious behavior of the community, especially parents. She stresses in her study that it is a time that consumes more effort and does laborious work to increase the participation of the community in the affairs of schools.

Rana (2014) revitalized a study in the province of Punjab to see the reforms in the field of education. He discussed the main causes of non-efficient school councils present in the educational institution of Punjab province which are as under

(a) Illiterate parents who did not take interest in the school affairs

(b) Lack of spare time for community members

(c) Incapable and non-creative local people of society.

(d) Like and dis-like procedure adopted in a selection of council selection.

(e) Un-skill people who didn't have an interest in school matters.

Habib (2014) conducted a study on the role of school councils in the process of the betterment of education, especially primary education. His study was focused on the exploration of the role of community in the progress of students. The results of the study found the considerable and significant role of community through school council cause the enhancement of school progress in addition with the efforts done by the government.

\section{Statement of the problem}

The problem under study was, "Participation of community in public sector schools of Khyber Pakhtunkhwa and Punjab regarding teaching-learning process (a case study of D.I.Khan and Bhakkar Districts)"

\section{Research Objectives}

The main focus and objective of this study were to find out the participation rate of the community in the functioning of public sector schools of Khyber Pakhtunkhwa and Punjab Provinces of Pakistan and make a comparison of this participation between two provinces.

\section{The procedure of Study}

This study was descriptive and deduced the perception of two groups of stakeholders' i.e. members of the committee and non-members of the committee. A self-developed tool i.e. questionnaire developed on a five-point Likert scale was developed. Validity of the tool was found through educationists/experts and by using a statistical package for social science version 21, Cronbach Alpha was calculated which was 0.89. Responses were collected from two groups of responses by using a validated and reliable tool consisting of 12 items. After getting responses the data was analyzed.

\section{Research Questions}

The study consisted of the following research questions.

1. Is there any participation of the community in the teaching-learning process according to the viewpoint of PTC members in Khyber Pakhtunkhwa?

2. Is there any participation of the community in the teaching-learning process according to the viewpoint of non-PTC members in Khyber Pakhtunkhwa?

3. Is there any participation of the community in the teaching-learning process according to the viewpoint of SMC members in Punjab?

4. Is there any participation of the community in the teaching-learning process according to the viewpoint of non-SMC members in Punjab?

\section{Hypotheses of research study}

$\mathrm{H}_{01}$ : There is no participation of the community through the Parents Teacher Council in the teaching-learning Process in public sector schools of Khyber Pakhtunkhwa.

$\mathrm{H}_{01 \mathrm{a}}$ : There is no participation of the community through PTC according to the viewpoint of PTC members. 
$\mathrm{H}_{011}$ : There is no participation of the community through PTC according to the viewpoint of non-PTC members.

$\mathrm{H}_{01 \mathrm{c}}$ : There is no participation of the community through PTC according to the viewpoint of PTC members and non-PTC members.

$\mathrm{H}_{02}$ : There is no participation of the community through the School Management Committee in the teaching-learning Process in public sector schools of Punjab.

$\mathrm{H}_{022}$ : There is no participation of the community through the School Management Committee according to the viewpoint of SMC members.

$\mathrm{H}_{02 \mathrm{~b}}$ : There is no participation of the community through the School Management Committee according to the viewpoint of non-SMC members.

$\mathrm{H}_{02 \mathrm{c}}$ : There is no participation of the community through the School Management Committee according to the viewpoint of SMC members and non-SMC members.

\section{Significance of Research Study}

It is crystal clear from different evidence that without ownership and involvement of the community in the business of schools especially in the process of teaching-learning, progress in school is not possible. This study was focus on the basic task of schools which is teaching and learning in two provinces of Pakistan i.e. Punjab and Khyber Pakhtunkhwa. The present study is very much significant as this provides the comparison of two districts that are situated in different provinces of Pakistan. This study is helpful to compare the implemented policies and participation rate of the community then provide a guideline for improvement. This study can be fruitful for mentioning and provide awareness regarding the responsibilities of different stakeholders. Moreover, this can also be because of motivation for the parents, teachers, and other communities to play their role actively with great enthusiasm and uplift the overall conditions of the school, especially in the teaching-learning process.

\section{RESEARCH METHODOLOGY}

\section{Population and Sample of the Study}

The population of the study consisted of 1182 Government primary schools in which 715 are in district Dear Ismail Khan, Khyber Pakhtunkhwa province, and 467 are located in district Bhakkar, Punjab province. Four stakeholders were included, two were from members of the selected committee and the other two were non-committee members. As each school has a selected body, the total population of committee members was 1182 chairmen and 1182 general secretaries, while the total population of non-committee members was $4339 \& 146955$ teachers and parents respectively. By using the population selection method described and adopted by (Krejcie \& Morgan). Total 460 schools were selected as a sample in which 250 from D.I.Khan Khyber Pakhtunkhwa while 210 were from Bhakkar Punjab.460 committee members i.e. chairmen and Secretaries each included while non-committee members 650 teachers and 764 parents were included in the sample.

Table 1: The population of the study was as under

\begin{tabular}{|c|c|c|c|c|c|c|c|c|}
\hline \multirow[b]{2}{*}{$\underset{\dot{n}}{\sum_{\infty}}$} & \multirow[b]{2}{*}{ Province } & \multirow[b]{2}{*}{$\begin{array}{l}\text { Name of } \\
\text { Districts }\end{array}$} & \multirow{2}{*}{$\begin{array}{l}\text { Number of } \\
\text { PTC/SMCs } \\
\text { Committees }\end{array}$} & \multicolumn{2}{|c|}{$\begin{array}{l}\text { Member related to PTC/SMC } \\
\text { Committee }\end{array}$} & \multicolumn{3}{|c|}{$\begin{array}{l}\text { Member not related to } \\
\text { PTC/SMC Committee }\end{array}$} \\
\hline & & & & $\begin{array}{l}\text { No. of } \\
\text { Chairmen }\end{array}$ & $\begin{array}{l}\text { No. of } \\
\text { G/Secretaries }\end{array}$ & $\begin{array}{l}\text { No of } \\
\text { Teachers }\end{array}$ & $\begin{array}{l}\text { Parents } \\
\text { school } \\
\text { children's }\end{array}$ & of \\
\hline 1 & $\begin{array}{l}\text { Khyber } \\
\text { Pakhtunkhwa }\end{array}$ & D.I.Khan & 715 & 715 & 715 & 2447 & 95831 & \\
\hline \multirow[t]{2}{*}{2} & Punjab & Bhakkar & 467 & 467 & 467 & 1840 & 61103 & \\
\hline & Total & & 1182 & 1182 & 1182 & 4287 & 156934 & \\
\hline
\end{tabular}

Source: Government of Khyber Pakhtunkhwa ASC (2017-18) \& GOP(2013) official website http/schools.punjab.gov.pk Krejcie and Morgan(1970) determination of sample rule

Table 2: The sample of the study is given below

\begin{tabular}{|c|c|c|c|c|c|c|c|}
\hline \multirow[b]{2}{*}{$\underset{z}{\dot{z}}$} & \multirow[b]{2}{*}{ Province } & \multirow[b]{2}{*}{$\begin{array}{l}\text { Name of } \\
\text { Districts }\end{array}$} & \multirow{2}{*}{$\begin{array}{l}\text { Number of } \\
\text { PTC/SMCs } \\
\text { Committees }\end{array}$} & \multicolumn{2}{|c|}{$\begin{array}{l}\text { Member related to PTC/SMC } \\
\text { Committee }\end{array}$} & \multicolumn{2}{|c|}{$\begin{array}{l}\text { Member not related to } \\
\text { PTC/SMC Committee }\end{array}$} \\
\hline & & & & $\begin{array}{l}\text { No. of } \\
\text { Chairmen }\end{array}$ & $\begin{array}{l}\text { No. of } \\
\text { G/Secretaries }\end{array}$ & $\begin{array}{l}\text { No of } \\
\text { Teachers }\end{array}$ & $\begin{array}{l}\text { Parents } \\
\text { school } \\
\text { children's }\end{array}$ \\
\hline 1 & $\begin{array}{l}\text { Khyber } \\
\text { Pakhtunkhwa }\end{array}$ & D.I.Khan & 250 & 250 & 250 & 332 & 382 \\
\hline
\end{tabular}




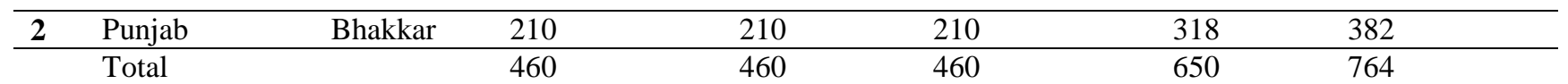

\section{Research tool}

The close-ended questionnaire was used to get responses from the stakeholders. The questionnaire has twelve items related to the process of teaching and learning at school.

\section{Validity of Research tool}

The questionnaire was used as a research tool which was developed on a five-point Likert scale in the light of related literature. For content validity, the tool was presented before the education experts. Pilot testing was done on a small sample of 10 stakeholders from each category. Statistical Package for Social Sciences(SPSS) was used to find reliability in this process by using Cronbach Alpha which was 0.89.for finding out the inter-item correlation, Pearson correlation was used and got significant at 0.005 level.

\section{Data Collection and Interpretation}

After the processing of the tool for validity and reliability, the valid and reliable tool was served to the stakeholders personally. After the collection of data, the researchers used Statistical Package for Social Sciences Version 20 for analysis of results, Means, Standard Deviation, T-distribution, and ANOVA used to find the results and draw inferences and then used for interpretations.

\section{ANALYSIS AND INTERPRETATION OF DATA}

Table 3: Shows Participation of the community in the teaching-learning process as per views of community members who are also members of the PTC Committee in Khyber Pakhtunkhwa

\begin{tabular}{|c|c|c|c|c|c|c|c|c|}
\hline S\# & Arranging curricular activities & $\begin{array}{l}\text { PTC } \\
\text { members }\end{array}$ & Mean & S.D & C.V & $\begin{array}{l}\text { t- } \\
\text { Calculated }\end{array}$ & $\begin{array}{l}\text { t- } \\
\text { tabulated }\end{array}$ & $\begin{array}{l}\mathbf{P} \text { - } \\
\text { value }\end{array}$ \\
\hline \multirow{2}{*}{1.} & \multirow{2}{*}{$\begin{array}{l}\text { Motivate parents for admission of Children } \\
\text { at School }\end{array}$} & Chairman & 4.12 & 0.55 & 19.61 & \multirow{2}{*}{2.14} & \multirow{2}{*}{ \pm 1.99} & \multirow{2}{*}{0.003} \\
\hline & & Secretory & 4.54 & 0.41 & 15.50 & & & \\
\hline \multirow{2}{*}{2.} & \multirow{2}{*}{ motivates the parents to reduce the dropout } & Chairman & 3.67 & 0.72 & 18.25 & \multirow{2}{*}{2.01} & \multirow{2}{*}{ \pm 1.99} & \multirow{2}{*}{0.005} \\
\hline & & Secretory & 4.32 & 0.67 & 16.16 & & & \\
\hline \multirow{2}{*}{3.} & \multirow{2}{*}{$\begin{array}{l}\text { Provision of education without gender } \\
\text { discrimination }\end{array}$} & Chairman & 3.89 & 0.71 & 11.73 & \multirow{2}{*}{3.41} & \multirow{2}{*}{ \pm 1.99} & \multirow{2}{*}{0.002} \\
\hline & & Secretory & 4.02 & 0.65 & 14.73 & & & \\
\hline \multirow{2}{*}{4.} & \multirow{2}{*}{ Encouragement of student } & Chairman & 4.43 & 0.52 & 12.93 & \multirow{2}{*}{1.89} & \multirow{2}{*}{ \pm 1.99} & \multirow{2}{*}{0.071} \\
\hline & & Secretory & 4.14 & 0.61 & 13.38 & & & \\
\hline \multirow[b]{2}{*}{5.} & \multirow[b]{2}{*}{ propagates the importance of education } & Chairman & 4.33 & 0.56 & 14.88 & \multirow[b]{2}{*}{2.27} & \multirow[b]{2}{*}{ \pm 1.99} & \multirow[b]{2}{*}{0.002} \\
\hline & & Secretory & 4.11 & 0.55 & 14.78 & & & \\
\hline \multirow{2}{*}{6.} & \multirow{2}{*}{ improves the overall learning environment } & Chairman & 4.03 & 0.60 & 16.79 & \multirow{2}{*}{-2.38} & \multirow{2}{*}{ \pm 1.99} & \multirow{2}{*}{0.003} \\
\hline & & Secretory & 3.99 & 0.59 & 14.03 & & & \\
\hline \multirow{2}{*}{7.} & \multirow{2}{*}{$\begin{array}{l}\text { Sensitizes teachers about the ban on } \\
\text { corporal punishment. }\end{array}$} & Chairman & 3.87 & 0.65 & 14.02 & & & \\
\hline & & Secretory & 4.06 & 0.57 & 9.168 & 2.33 & \pm 1.99 & 0.000 \\
\hline & 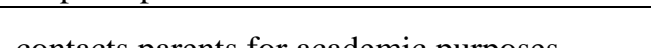 & Chairman & 4.42 & 0.62 & 16.12 & & & 0000 \\
\hline 8. & contacts parents for academic purposes & Secretory & 4.69 & 0.43 & 13.42 & 2.52 & \pm 1.99 & 0.000 \\
\hline 0 & Dicoures the oramination molts & Chairman & 4.03 & 0.65 & 13.81 & & 100 & 0004 \\
\hline 9. & Discusses the examination results. & Secretory & 4.32 & 0.58 & 14.86 & 2.86 & \pm 1.99 & 0.004 \\
\hline 10 & Dicoucc oducotionel nrobleme of the cohool & Chairman & 4.27 & 0.59 & 17.58 & & 100 & 0002 \\
\hline 10. & Discuss educational problems of the school & Secretory & 4.44 & 0.66 & 15.40 & 2.96 & \pm 1.99 & 0.002 \\
\hline 11 & contacts parents to minimize the & Chairman & 3.98 & 0.70 & 13.38 & 310 & +100 & $0 \Omega 00$ \\
\hline 11 . & absenteeism & Secretory & 4.09 & 0.63 & 12.47 & 3.10 & \pm 1.99 & 0.000 \\
\hline 12 & Diccucces the nerformance of teachers & Chairman & 4.26 & 0.57 & 19.61 & 281 & +100 & 0001 \\
\hline 12. & Discusses the performance of teachers & Secretory & 4.33 & 0.54 & 15.50 & 2.81 & \pm 1.99 & 0.001 \\
\hline
\end{tabular}

At 0.05 level of Significance

Mention the significance level in the table as well. For 0.05 level *, $0.01 * *$ and - for non significant.

The above table reflects the analysis about the perception of the first group of stakeholders' i.e. PTC members consist of responses of the PTC Chairmen and Secretaries about the participation of the community in the teaching-learning process in the public sector primary school in Khyber Pakhtunkhwa. Detailed reflection analysis is given as under:

The first item reflects the viewpoint of the respondents to get their children admitted to the school. The responses of chairmen of PTC are 4.12 while the mean values of respondent no. 2 who are secretary as well as the head of the institution are 4.54. As the range of mean value is 01 to 05 and the result of both respondents is greater than 2.5 which 
shows the participation of the community for this item. The value of the coefficient of variation (C.V) for chairmen and secretaries is 19.61 and 15.50 respectively elucidates the less dispersion in the viewpoints of both but the secretaries are more focused than chairmen and the majority agree on it. As the P-value (0.003) of the responses of both the respondents is less than 0.05 and the value of $t$-calculated (2.14) is greater than $t$-tabulated $( \pm 1.99)$ which leads to the acceptance of $\mathrm{H}_{1}$ which says there is significant participation of community through PTC in the teaching-learning process in the schools of Khyber Pakhtunkhwa.

The second item reflects the viewpoint of the respondents to motivate parents to reduce the dropout in the school. The responses of chairmen of PTC are 3.67 while the mean value of respondent no.2 who is the secretary as well as the head of the institution is 4.32 . As the range of mean value is 01 to 05 and the result of both respondents is greater than 2.5 which shows the participation of the community for this item. The value of the coefficient of variation (C.V) for chairmen and secretaries is 18.25 and 16.16respectively elucidates the less dispersion in the viewpoints of both but the secretaries are more focused than chairmen and the majority agrees on it. As the P-value (0.005) of the responses of both the respondents is less than 0.05 and the value of $t$-calculated (2.01) is greater than $t$-tabulated $( \pm 1.99)$ which leads to the acceptance of $\mathrm{H}_{1}$ which says there is significant participation of community through PTC in the teaching-learning process in the schools of Khyber Pakhtunkhwa.

The third item reflects the viewpoint of the respondents to provide education without gender discrimination. The responses of chairmen of PTC are 3.89 while the mean values of respondent no. 2 who are secretary as well as the head of the institution are 4.02. As the range of mean value is 01 to 05 and the result of both respondents is greater than 2.5 which shows the participation of the community for this item. The value of the coefficient of variation (C.V) for chairmen and secretaries is 11.73 and 14.73 respectively elucidates the less dispersion in the viewpoints of both but the secretaries are more focused than chairmen and the majority agrees on it. As the P-value (0.002) of the responses of both the respondents is less than 0.05 and the value of $t$-calculated (2.01) is greater than t-tabulated $( \pm 1.99)$ which leads to the acceptance of $\mathrm{H}_{1}$ which says there is significant participation of community through PTC in the teaching-learning process in the schools of Khyber Pakhtunkhwa.

The fourth item reflects the viewpoint of the respondents to encourage the students. The responses of chairmen of PTC are 4.43 while the mean values of respondent no. 2 who are secretary as well as the head of the institution are 4.14 . As the range of mean value is 01 to 05 and the result of both respondents is greater than 2.5 which shows the participation of the community for this item. The value of the coefficient of variation (C.V) for chairmen and secretaries is 12.93 and 13.38 respectively elucidates the less dispersion in the viewpoints of both but the chairmen are more focused than Secretaries and the majority agrees on it. As the P-value (0.071) of the responses of both the respondents is greater than 0.05 and the value of $t$-calculated (1.89) is less than $t$-tabulated ( \pm 1.99 ) which leads to the acceptance of $\mathrm{H}_{0}$ which says there is no significant participation of community through PTC in the teaching-learning process in the schools of Khyber Pakhtunkhwa.

The fifth item reflects the viewpoint of the respondents to propagate the importance of education. The responses of chairmen of PTC are 4.33 while the mean values of respondent no.2 who are secretary as well as the head of the institution are 4.11. As the range of mean value is 01 to 05 and the result of both respondents is greater than 2.5 which shows the participation of the community for this item. The value of the coefficient of variation (C.V) for chairmen and secretaries is 14.88 and 14.78 respectively elucidates the less dispersion in the viewpoints of both but the chairmen are more focused than secretaries and the majority agrees on it. As the P-value $(0.002)$ of the responses of both the respondents is less than 0.05 and the value of $t$-calculated $(2.27)$ is greater than $t$-tabulated $( \pm 1.99)$ which leads to the acceptance of $\mathrm{H}_{1}$ which says there is significant participation of community through PTC in the teaching-learning process in the schools of Khyber Pakhtunkhwa.

The sixth item reflects the viewpoint of the respondents to improve the overall learning environment The responses of chairmen of PTC are 4.03 while the mean value of respondent no. 2 who is secretary as well as the head of the institution is 3.99. As the range of mean value is 01 to 05 and the result of both respondents is greater than 2.5 which shows the participation of the community for this item. The value of the coefficient of variation (C.V) for chairmen and secretaries is 16.79 and 14.03 respectively elucidates the less dispersion in the viewpoints of both but the chairmen are more focused than secretaries and the majority agrees on it. As the P-value (0.003) of the responses of both the respondents is less than 0.05 and the value of $\mathrm{t}$-calculated $(-2.38)$ is in not fall in the acceptance region as t-tabulated $( \pm 1.99)$ which leads to the acceptance of $\mathrm{H}_{1}$ which says there is significant participation of community through PTC in the teachinglearning process in the schools of Khyber Pakhtunkhwa.

The seventh item reflects the viewpoint of the respondents to sensitize teachers about a ban on corporal punishment in educational institutions. The responses of chairmen of PTC are 3.87 while the mean value of respondent no. 2 who is the secretary as well as the head of the institution is 4.06. As the range of mean value is 01 to 05 and the result of both respondents is greater than 2.5 which shows the participation of the community for this item. The value of the coefficient of variation (C.V) for chairmen and secretaries is 14.02 and 09.168 respectively elucidates the less dispersion in the viewpoints of both but the Secretaries are more focused than Chainmen and the majority agrees on it. As the P-value $(0.000)$ of the responses of both the respondents is less than 0.05 and the value of $t$-calculated (2.33) is greater than $t-$ 
tabulated $( \pm 1.99)$ which leads to the acceptance of $\mathrm{H}_{1}$ which says there is significant participation of community through PTC in the teaching-learning process in the schools of Khyber Pakhtunkhwa.

The eighth item reflects the viewpoint of the respondents to contact parents for academic purposes and punishment in educational institutions. The responses of chairmen of PTC are 4.42 while the mean values of respondent no. 2 who are secretary as well as the head of the institution are 4.69. As the range of mean value is 01 to 05 and the result of both respondents is greater than 2.5 which shows the participation of the community for this item. The value of the coefficient of variation (C.V) for chairmen and secretaries is 16.12 and 13.42 respectively elucidates the less dispersion in the viewpoints of both but the Secretaries are more focused than Chainmen and the majority agree on it. As the P-value $(0.000)$ of the responses of both the respondents is less than 0.05 and the value of t-calculated (2.52) is greater than $t-$ tabulated $( \pm 1.99)$ which leads to the acceptance of $\mathrm{H}_{1}$ which says there is significant participation of community through PTC in the teaching-learning process in the schools of Khyber Pakhtunkhwa.

The ninth item reflects the viewpoint of the respondents to contact parents to discuss the examination results with parents' educational institutions. The responses of chairmen of PTC are 4.03 while the mean values of respondent no. 2 who are secretary as well as the head of the institution are 4.32. As the range of mean value is 01 to 05 and the result of both respondents is greater than 2.5 which shows the participation of the community for this item. The value of the coefficient of variation (C.V) for chairmen and secretaries is 13.81 and 14.86 respectively elucidates the less dispersion in the viewpoints of both but the Secretaries are more focused than Chainmen and the majority agrees on it. As the Pvalue (0.004) of the responses of both the respondents is less than 0.05 and the value of $t$-calculated (2.86) is greater than t-tabulated $( \pm 1.99)$ which leads to the acceptance of $\mathrm{H}_{1}$ which says there is significant participation of community through PTC in the teaching-learning process in the schools of Khyber Pakhtunkhwa.

The tenth item reflects the viewpoint of the respondents to discuss educational problems of the school with parents in educational institutions. The responses of chairmen of PTC are 4.27 while the mean value of respondent no. 2 who is the secretary as well as the head of the institution is 4.44. As the range of mean value is 01 to 05 and the result of both respondents is greater than 2.5 which shows the participation of the community for this item. The value of the coefficient of variation (C.V) for chairmen and secretaries is 17.58 and 15.40 respectively elucidates the less dispersion in the viewpoints of both but the Secretaries are more focused than Chainmen and the majority agrees on it. As the P-value (0.007) of the responses of both the respondents is less than 0.05 and the value of t-calculated (2.96) is greater than ttabulated $( \pm 1.99)$ which leads to the acceptance of $\mathrm{H}_{1}$ which says there is significant participation of community through PTC in the teaching-learning process in the schools of Khyber Pakhtunkhwa.

The eleventh item reflects the viewpoint of the respondents to contact parents to minimize absenteeism in educational institutions. The responses of chairmen of PTC are 3.98 while the mean values of respondent no. 2 who are secretary as well as the head of institution is 4.09 . As the range of mean value is 01 to 05 and the result of both respondents is greater than 2.5 which shows the participation of the community for this item. The value of the coefficient of variation (C.V) for chairmen and secretaries is 13.38 and 12.47 respectively elucidates the less dispersion in the viewpoints of both but the Secretaries are more focused than Chainmen and the majority agrees on it. As the P-value $(0.000)$ of the responses of both the respondents is less than 0.05 and the value of t-calculated (3.10) is greater than t-tabulated $( \pm 1.99)$ which leads to the acceptance of $\mathrm{H}_{1}$ which says there is significant participation of community through PTC in the teaching-learning process in the schools of Khyber Pakhtunkhwa.

The twelfth item reflects the viewpoint of the respondents to discuss the performance of teachers in educational institutions. The responses of chairmen of PTC are 4.26 while the mean value of respondent no. 2 who is the secretary as well as the head of the institution is 4.33. As the range of mean value is 01 to 05 and the result of both respondents is greater than 2.5 which shows the participation of the community for this item. The value of the coefficient of variation (C.V) for chairmen and secretaries is 19.61 and 15.50 respectively elucidates the less dispersion in the viewpoints of both but the Secretaries are more focused than Chainmen and the majority agree on it. As the P-value (0.001) of the responses of both the respondents is less than 0.05 and the value of t-calculated (2.81) is greater than t-tabulated $( \pm 1.99)$ which leads to the acceptance of $\mathrm{H}_{1}$ which says there is significant participation of community through PTC in the teaching-learning process in the schools of Khyber Pakhtunkhwa.

Table 4: Shows Participation of the community in the teaching-learning process as per views of community members who are not members of the PTC Committee in Khyber Pakhtunkhwa

\begin{tabular}{|c|c|c|c|c|c|c|c|c|}
\hline S\# & Arranging curricular activities & $\begin{array}{l}\text { PTC } \\
\text { members }\end{array}$ & Mean & S.D & C.V & $\begin{array}{l}\text { t- } \\
\text { Calculated }\end{array}$ & $\begin{array}{l}\text { t- } \\
\text { tabulated }\end{array}$ & $\begin{array}{l}\mathbf{P}- \\
\text { value }\end{array}$ \\
\hline \multirow{2}{*}{1.} & \multirow{2}{*}{$\begin{array}{l}\text { Motivate parents for admission of Children } \\
\text { at School }\end{array}$} & Parent & 4.21 & 0.45 & 10.69 & \multirow[b]{2}{*}{2.41} & \multirow{2}{*}{ \pm 1.99} & \multirow{2}{*}{0.007} \\
\hline & & Teacher & 3.93 & 0.47 & 11.96 & & & \\
\hline \multirow{2}{*}{2.} & \multirow{2}{*}{ motivates the parents to reduce the dropout } & Parent & 3.42 & 0.52 & 15.20 & \multirow{2}{*}{2.22} & \multirow{2}{*}{ \pm 1.99} & \multirow{2}{*}{0.005} \\
\hline & & Teacher & 3.36 & 0.57 & 16.96 & & & \\
\hline \multirow{2}{*}{3.} & \multirow{2}{*}{$\begin{array}{l}\text { Provision of education } \\
\text { discrimination }\end{array}$} & Parent & 3.89 & 0.49 & 12.59 & \multirow{2}{*}{3.01} & \multirow{2}{*}{ \pm 1.99} & \multirow{2}{*}{0.000} \\
\hline & & Teacher & 4.32 & 0.51 & 11.81 & & & \\
\hline 4. & Encouragement of student & Parent & 4.34 & 0.52 & 11.98 & -2.47 & \pm 1.99 & 0.001 \\
\hline
\end{tabular}


https://doi.org/10.18510/hssr.2021.93167

\begin{tabular}{|c|c|c|c|c|c|c|c|c|}
\hline & & Teacher & 4.22 & 0.58 & 13.74 & & & \\
\hline & \multirow[b]{2}{*}{ propagates the importance of education } & Parent & 4.27 & 0.56 & 13.11 & \multirow[b]{2}{*}{2.49} & \multirow[b]{2}{*}{ \pm 1.99} & \multirow[b]{2}{*}{0.002} \\
\hline & & Teacher & 4.11 & 0.53 & 12.89 & & & \\
\hline \multirow{2}{*}{6.} & \multirow{2}{*}{ improves the overall learning environment } & Parent & 4.01 & 0.55 & 13.71 & \multirow{2}{*}{2.78} & \multirow{2}{*}{ \pm 1.99} & \multirow{2}{*}{0.005} \\
\hline & & Teacher & 3.99 & 0.59 & 14.78 & & & \\
\hline & \multirow{2}{*}{$\begin{array}{l}\text { Sensitizes teachers about the ban on } \\
\text { corporal punishment. }\end{array}$} & Parent & 4.31 & 0.53 & 12.29 & \multirow{2}{*}{2.14} & \multirow{2}{*}{ \pm 1.99} & \multirow{2}{*}{0.001} \\
\hline & & Teacher & 4.10 & 0.61 & 14.87 & & & \\
\hline \multirow{2}{*}{\multicolumn{2}{|c|}{ ademic purposes }} & Parent & 4.38 & 0.59 & 13.47 & \multirow{2}{*}{2.77} & \multirow{2}{*}{ \pm 1.99} & \multirow{2}{*}{0.000} \\
\hline & & Teacher & 4.03 & 0.56 & 13.89 & & & \\
\hline & \multirow{2}{*}{ Discusses the examination results. } & Parent & 4.44 & 0.47 & 10.58 & \multirow{2}{*}{3.01} & \multirow{2}{*}{ \pm 1.99} & \multirow{2}{*}{0.005} \\
\hline & & Teacher & 4.72 & 0.41 & 8.686 & & & \\
\hline & \multirow{2}{*}{ Discuss educational problems of the school } & Parent & 3.84 & 0.57 & 14.84 & \multirow{2}{*}{3.08} & \multirow{2}{*}{ \pm 1.99} & \multirow{2}{*}{0.004} \\
\hline & & Teacher & 4.26 & 0.49 & 11.50 & & & \\
\hline \multirow{2}{*}{\multicolumn{2}{|c|}{$\begin{array}{l}\text { contacts parents } \\
\text { absenteeism }\end{array}$}} & Parent & 4.20 & 0.52 & 12.38 & \multirow{2}{*}{2.77} & \multirow{2}{*}{ \pm 1.99} & \multirow{2}{*}{0.000} \\
\hline & & Teacher & 4.31 & 0.57 & 13.22 & & & \\
\hline \multirow{2}{*}{\multicolumn{2}{|c|}{ Discusses the performance of teachers }} & Parent & 3.98 & 0.61 & 15.33 & \multirow{2}{*}{3.01} & \multirow{2}{*}{ \pm 1.99} & 0005 \\
\hline & & Teacher & 4.47 & 0.58 & 12.98 & & & \\
\hline
\end{tabular}

The above table reflects the perception of non-PTC members who are also part of the community and have a keen interest in the affairs of schools as their children are studying there or they perform in these educational institutions. The mean values of both the respondents (teacher and parent) range from 1 to 5 and their responses reflect that under all items mean values are above the average i.e. 2.4 which elucidates that as per the perception of this group the community has a higher participation rate in the affairs of schools. Since $p$ values range from $(0.000$ to 0.009$)$ which are less than 0.05 reflects that there is significant dereference in the perception of both respondents but strongly in favor of community participation. Similarly, the coefficient of variation ranges from 8.686 to 16.96 which displays the less dispersion rate.

Table 5: Shows Participation of the community in the teaching-learning process as per views of community members who are also members of the SMC Committee in Punjab

\begin{tabular}{|c|c|c|c|c|c|c|c|c|c|}
\hline S\# & & Arranging curricular activities & $\begin{array}{l}\text { PTC } \\
\text { members }\end{array}$ & Mean & S.D & C.V & $\begin{array}{l}\text { t- } \\
\text { Calculated }\end{array}$ & $\begin{array}{l}\text { t- } \\
\text { tabulated }\end{array}$ & $\begin{array}{l}\text { P- } \\
\text { value }\end{array}$ \\
\hline \multirow{2}{*}{1.} & \multirow{2}{*}{\multicolumn{2}{|c|}{$\begin{array}{l}\text { Motivate parents for admission of } \\
\text { Children at School }\end{array}$}} & Chairman & 4.02 & 0.56 & 13.93 & \multirow{2}{*}{2.13} & \multirow{2}{*}{ \pm 1.99} & \multirow{2}{*}{0.001} \\
\hline & & & Secretory & & 0.51 & 11.56 & & & \\
\hline \multirow{2}{*}{2.} & \multirow{2}{*}{\multicolumn{2}{|c|}{$\begin{array}{l}\text { motivates the parents to reduce the } \\
\text { dropout }\end{array}$}} & & & 0.62 & 18.08 & \multirow{2}{*}{2.01} & \multirow{2}{*}{ \pm 1.99} & \multirow{2}{*}{0.006} \\
\hline & & & & & .61 & & & & \\
\hline \multirow{2}{*}{3.} & \multirow{2}{*}{3} & \multirow{2}{*}{$\begin{array}{l}\text { Provision of education without gender } \\
\text { discrimination }\end{array}$} & & & & & \multirow{2}{*}{2.79} & \multirow{2}{*}{ \pm 1.99} & \multirow{2}{*}{0.003} \\
\hline & & & & & & & & & \\
\hline \multirow{2}{*}{4.} & \multirow{2}{*}{4} & \multirow{2}{*}{ Encouragement of student } & & & & & \multirow{2}{*}{2.43} & \multirow{2}{*}{ \pm 1.99} & \multirow{2}{*}{0.000} \\
\hline & & & & & 0.49 & 11. & & & \\
\hline \multirow{2}{*}{5.} & \multirow{2}{*}{5} & \multirow{2}{*}{$\begin{array}{l}\text { propagates the importance of } \\
\text { education }\end{array}$} & & & 0.61 & 15.02 & \multirow{2}{*}{-2.31} & \multirow{2}{*}{ \pm 1.99} & \multirow{2}{*}{0.002} \\
\hline & & & & & 0.59 & 13.95 & & & \\
\hline \multirow{2}{*}{6.} & \multirow{2}{*}{6} & \multirow{2}{*}{$\begin{array}{l}\text { improves the } \\
\text { environment }\end{array}$} & & & & & \multirow{2}{*}{3.06} & +1.99 & 0001 \\
\hline & & & & $\overline{43}$ & 0.63 & 14.55 & & \pm 1.99 & 0.001 \\
\hline 7. & & Sensitizes teachers & Cha & & 0.71 & 18.88 & 21 & & 0.000 \\
\hline 1. & 1 & & & 3.8 & 0.68 & & & & 0.000 \\
\hline 8 & 8 & contacts parents for & Chairman & 4.02 & 0.54 & 13.43 & & & 0002 \\
\hline & & & & & 0.53 & & & & 0.002 \\
\hline 9. & 9 & Discusses the examination results. & Chairn & & 0. & & & & 0001 \\
\hline & & & & & 0.51 & & & & \\
\hline 10 & 1 & Discuss educational problems of the & & & 0.72 & 18. & & & 0006 \\
\hline 10. & 1 & & & & 0.58 & & & & 0.006 \\
\hline 11. & 1 & contacts parents to minimize the & Chairman & 3.96 & 0.68 & 17.17 & & & \\
\hline 11. & & & & 4.01 & 0.67 & 16.71 & & & \\
\hline 12. & 1 & Discusses the performance of teachers & Chairman & 3.88 & 0.66 & 17.01 & & & 0.000 \\
\hline & 1 & 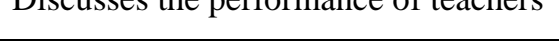 & Secretory & 4.06 & 0.59 & 14.53 & & & \\
\hline
\end{tabular}

The above table reflects the analysis about the perception of the second group of stakeholders' i.e SMC members consists of responses of the SMC Chairmen and Secretaries about the participation of the community in the teaching-learning process in the public sector primary school in Punjab. Detailed reflection analysis is given as under: 
The first item reflects the viewpoint of the respondents to get their children admitted to the school. The responses of chairmen of SMC who are the head of the institution too are 4.02 while the mean values of respondent no. 2 who are secretary are 4.41. As the range of mean value is 01 to 05 and the result of both respondents is greater than 2.5 which shows the participation of the community for this item. The value of the coefficient of variation (C.V) for chairmen and secretaries is 13.93 and 11.56 respectively elucidates the less dispersion in the viewpoints of both but the secretaries are more focused than chairmen and the majority agrees on it. As the P-value (0.001) of the responses of both the respondents is less than 0.05 and the value of $t$-calculated (2.13) is greater than $t$-tabulated $( \pm 1.99)$ which leads to the acceptance of $\mathrm{H}_{1}$ which says there is significant participation of community through SMCs in the teaching-learning process in the schools of Punjab.

The second item reflects the viewpoint of the respondents to motivate parents to reduce the dropout in the school. The responses of chairmen of SMC who are head of the institute too are 3.78 while the mean values of respondent no. 2 who are secretary are 3.78. As the range of mean value is 01 to 05 and the result of both respondents is greater than 2.5 which shows the participation of the community for this item. The value of the coefficient of variation (C.V) for chairmen and secretaries is 18.08 and 16.14 respectively elucidates the less dispersion in the viewpoints of both but the secretaries are more focused than chairmen and the majority agrees on it. As the P-value (0.006) of the responses of both the respondents is less than 0.05 and the value of $t$-calculated (2.01) is greater than $t$-tabulated $( \pm 1.99)$ which leads to the acceptance of $\mathrm{H}_{1}$ which says there is a significant difference in the perception of viewpoints of stakeholders regarding the participation of community through SMC in the teaching-learning process in the schools of Punjab.

The third item reflects the viewpoint of the respondents to provide education without gender discrimination. The responses of chairmen of SMC who are head of the institution too are 4.21 while the mean values of respondent no. 2 who are secretary are 4.14. As the range of mean value is 01 to 05 and the result of both respondents is greater than 2.5 which shows the participation of the community for this item. The value of the coefficient of variation (C.V) for chairmen and secretaries is 10.31 and 11.04 respectively elucidates the less dispersion in the viewpoints of both but the Chairmen are more focused than secretaries and the majority agrees on it. As the P-value (0.003) of the responses of both the respondents is less than 0.05 and the value of $t$-calculated $(2.79)$ is greater than $t$-tabulated $( \pm 1.99)$ which leads to the acceptance of $\mathrm{H}_{1}$ which says that there is a significant difference in the perception of viewpoints of stakeholders but favor regarding the participation of community through SMC in the teaching-learning process in the schools of Punjab.

The fourth item reflects the viewpoint of the respondents to encourage the students. The responses of chairmen of SMC who are head of the institute also are 4.56 while the mean values of respondent no. 2 who are secretary are 4.44 . As the range of mean value is 01 to 05 and the result of both respondents is greater than 2.5 which shows the participation of the community for this item. The value of the coefficient of variation (C.V) for chairmen and secretaries is 10.31 and 11.01 respectively elucidates the less dispersion in the viewpoints of both but the chairmen are more focused than Secretaries and the majority agree on it. As the P-value (0.0000) of the responses of both the respondents is greater than 0.05 and the value of $t$-calculated $(2.43)$ is greater than t-tabulated $( \pm 1.99)$ which leads to the acceptance of $H_{1}$ which says that there is a significant difference in the perception of viewpoints of stakeholders but favor regarding the participation of community through SMC in the teaching-learning process in the schools of Punjab.

The fifth item reflects the viewpoint of the respondents to propagate the importance of education. The responses of chairmen of SMC who are head of the institute too are 4.06 while the mean values of respondent no. 2 who are secretary are 4.23. As the range of mean value is 01 to 05 and the result of both respondents is greater than 2.5 which shows the participation of the community for this item. The value of the coefficient of variation $(\mathrm{C} . \mathrm{V})$ for chairmen and secretaries is 15.02 and 13.95 respectively elucidates the less dispersion in the viewpoints of both but the Secretaries are more focused than chairmen and the majority agrees on it. As the P-value (0.002) of the responses of both the respondents is less than 0.05 and the value of $t$-calculated $(-2.31)$ is greater than t-tabulated $( \pm 1.99)$ which leads to the acceptance of $\mathrm{H}_{1}$ which says that there is a significant difference in the perception of viewpoints of stakeholders but favor regarding the participation of community through SMC in the teaching-learning process in the schools of Punjab.

The sixth item reflects the viewpoint of the respondents to improve the overall learning environment. The mean value of responses of chairmen of SMC which are heads of the institute too is 4.10 while the mean values of respondent no. 2 who are secretaries are 4.33. As the range of mean value is 01 to 05 and the result of both respondents is greater than 2.5 which shows the participation of the community for this item. The value of the coefficient of variation (C.V) for chairmen and secretaries is 16.59 and 14.55 respectively elucidates the less dispersion in the viewpoints of both but secretaries are more focused than chairmen and the majority agree on it. As the P-value $(0.001)$ of the responses of both the respondents is less than 0.05 and the value of t-calculated (3.06) is in not fall in the acceptance region as t-tabulated $( \pm 1.99)$ which leads to the acceptance of $\mathrm{H}_{1}$ which says that there is a significant difference in the perception of viewpoints of stakeholders but favor regarding the participation of community through SMC in the teaching-learning process in the schools of Punjab.

The seventh item reflects the viewpoint of the respondents to sensitize teachers about the ban on corporal punishment in educational institutions. The mean values of responses of chairmen of SMC who are head of the institute too are 3.76 while the mean values of respondent no.2 who are secretary are 3.89. As the range of mean value is 01 to 05 and the 
result of both respondents is greater than 2.5 which shows the participation of the community for this item. The value of the coefficient of variation (C.V) for chairmen and secretaries is 18.88 and 17.43 respectively elucidates the less dispersion in the viewpoints of both but the Secretaries are more focused than Chainmen and the majority agrees on it. As the P-value (0.000) of the responses of both the respondents is less than 0.05 and the value of t-calculated (2.12) is greater than $\mathrm{t}$-tabulated $( \pm 1.99)$ which leads to the acceptance of $\mathrm{H}_{1}$ which says that there is a significant difference in the perception of viewpoints of stakeholders but favor regarding the participation of community through SMC in the teaching-learning process in the schools of Punjab.

The eighth item reflects the viewpoint of the respondents to contact parents for academic purposes and punishment in educational institutions. The mean values of responses of chairmen of SMC who are head of the institute too are 4.02 while the mean values of respondent no. 2 who are secretary are 4.17. As the range of mean value is 01 to 05 and the result of both respondents is greater than 2.5 which shows the participation of the community for this item. The value of the coefficient of variation (C.V) for chairmen and secretaries is 13.43 and 12.71 respectively elucidates the less dispersion in the viewpoints of both but the Secretaries are more focused than Chainmen and the majority agrees on it. As the P-value (0.002) of the responses of both the respondents is less than 0.05 and the value of $t$-calculated (2.41) is greater than t-tabulated $( \pm 1.99)$ which leads to the acceptance of $\mathrm{H}_{1}$ which says that there is a significant difference in the perception of viewpoints of stakeholders but favor regarding the participation of community through SMC in the teaching-learning process in the schools of Punjab.

The ninth item reflects the viewpoint of the respondents to contact parents to discuss the examination results with parents. The mean values of responses of chairmen of SMC who are head of the institute also are 4.30 while the mean values of respondent no. 2 who are secretary are 4.54. As the range of mean value is 01 to 05 and the result of both respondents is greater than 2.5 which shows the participation of the community for this item. The value of the coefficient of variation (C.V) for chairmen and secretaries is 13.72 and 11.23 respectively elucidates the less dispersion in the viewpoints of both but the Secretaries are more focused than Chainmen and the majority agrees on it. As the P-value (0.001) of the responses of both the respondents is less than 0.05 and the value of $t$-calculated (2.08) is greater than $t-$ tabulated $( \pm 1.99)$ which leads to the acceptance of $\mathrm{H}_{1}$ which says that there is a significant difference in the perception of viewpoints of stakeholders but favor regarding the participation of community through SMC in the teaching-learning process in the schools of Punjab.

The tenth item reflects the viewpoint of the respondents to discuss educational problems of the school with parents in educational institutions. The responses of chairmen of SMC who are head of the institution are 3.99 while the mean values of respondent no. 2 who are secretary are 4.11. As the range of mean value is 01 to 05 and the result of both respondents is greater than 2.5 which shows the participation of the community for this item. The value of the coefficient of variation (C.V) for chairmen and secretaries is 18.05 and 14.11 respectively elucidates the less dispersion in the viewpoints of both but the Secretaries are more focused than Chainmen and the majority agrees on it. As the P-value (0.006) of the responses of both the respondents is less than 0.05 and the value of $t$-calculated $(-2.16)$ is greater than $t-$ tabulated $( \pm 1.99)$ which leads to the acceptance of $\mathrm{H}_{1}$ which says that there is a significant difference in the perception of viewpoints of stakeholders but favor regarding the participation of community through SMC in the teaching-learning process in the schools of Punjab.

The eleventh item reflects the viewpoint of the respondents to contact parents to minimize absenteeism in educational institutions. The responses of chairmen of SMC who are head of the institute too are 3.96 while the mean values of respondent no. 2 who are secretary are 4.01. As the range of mean value is 01 to 05 and the result of both respondents is greater than 2.5 which shows the participation of the community for this item. The value of the coefficient of variation (C.V) for chairmen and secretaries is 17.17 and 16.71 respectively elucidates the less dispersion in the viewpoints of both but the Secretaries are more focused than Chainmen and the majority agrees on it. As the P-value $(0.002)$ of the responses of both the respondents is less than 0.05 and the value of $t$-calculated (2.83) is greater than $t$-tabulated $( \pm 1.99)$ which leads to the acceptance of $\mathrm{H}_{1}$ which says that there is a significant difference in the perception of viewpoints of stakeholders but favor regarding the participation of community through SMC in the teaching-learning process in the schools of Punjab.

The twelfth item reflects the viewpoint of the respondents to discuss the performance of teachers in educational institutions. The responses of chairmen of SMC who are head of the institute too are 3.88 while the mean values of respondent no. 2 who are secretary are 4.06. As the range of mean value is 01 to 05 and the result of both respondents is greater than 2.5 which shows the participation of the community for this item. The value of the coefficient of variation (C.V) for chairmen and secretaries is 17.01 and 14.53 respectively elucidates the less dispersion in the viewpoints of both but the Secretaries are more focused than Chainmen and the majority agree on it. As the P-value (0.000) of the responses of both the respondents is less than 0.05 and the value of $t$-calculated (2.93) is greater than $t$-tabulated $( \pm 1.99)$ which leads to the acceptance of $\mathrm{H}_{1}$ which says that there is a significant difference in the perception of viewpoints of stakeholders but favor regarding the participation of community through SMC in the teaching-learning process in the schools of Punjab. 
Table 6: Shows Participation of the community in the teaching-learning process as per views of community members who are not members of the SMC Committee in Punjab

\begin{tabular}{|c|c|c|c|c|c|c|c|c|}
\hline S\# & Arranging curricular activities & $\begin{array}{l}\text { PTC } \\
\text { members }\end{array}$ & Mean & S.D & C.V & $\begin{array}{l}\text { t- } \\
\text { Calculated }\end{array}$ & $\begin{array}{l}\text { t- } \\
\text { tabulated }\end{array}$ & $\begin{array}{l}\text { P- } \\
\text { value }\end{array}$ \\
\hline \multirow[b]{2}{*}{1.} & \multirow{2}{*}{$\begin{array}{l}\text { Motivate parents for admission of Children } \\
\text { at School }\end{array}$} & Parent & 3.76 & 0.69 & 18.35 & \multirow{2}{*}{3.12} & \multirow{2}{*}{ \pm 1.99} & \multirow{2}{*}{0.001} \\
\hline & & Teacher & & & & & & \\
\hline \multirow{2}{*}{2.} & \multirow{2}{*}{ motivates the parents to reduce the dropout } & Parent & 3.12 & & .36 & \multirow{2}{*}{2.33} & \multirow{2}{*}{ \pm 1.99} & \multirow{2}{*}{0.004} \\
\hline & & Teacher & 3.45 & 0.70 & 20.29 & & & \\
\hline \multirow{2}{*}{3.} & \multirow{2}{*}{$\begin{array}{l}\begin{array}{l}\text { Provision of education without gender } \\
\text { discrimination }\end{array} \\
\end{array}$} & Parent & 3.77 & 0.67 & 17.77 & \multirow{2}{*}{2.46} & \multirow{2}{*}{ \pm 1.99} & \multirow{2}{*}{0.000} \\
\hline & & Teacher & 4.21 & 0.65 & 15.44 & & & \\
\hline \multirow{2}{*}{4.} & \multirow{2}{*}{ Encouragement of student } & Parent & 3.92 & 0.72 & 18.37 & \multirow{2}{*}{-3.06} & \multirow{2}{*}{ \pm 1.99} & \multirow{2}{*}{0.003} \\
\hline & & & & & & & & \\
\hline \multirow{2}{*}{5.} & \multirow{2}{*}{ propagates the importance of education } & & & 0. & & \multirow{2}{*}{-2.87} & \multirow{2}{*}{ \pm 1.99} & \multirow{2}{*}{0.001} \\
\hline & & $\mathrm{Te}$ & 4.42 & 0.63 & 14.25 & & & \\
\hline \multirow{2}{*}{6.} & \multirow{2}{*}{ improves the overall learning environment } & & 3.6 & 0.67 & 18.26 & \multirow{2}{*}{2.1} & \multirow{2}{*}{ \pm 1.99} & \multirow{2}{*}{0.002} \\
\hline & & Teacher & 4.07 & 0.64 & 15.72 & & & \\
\hline \multirow{2}{*}{7.} & \multirow{2}{*}{$\begin{array}{l}\text { Sensitizes teachers about the ban on } \\
\text { corporal punishment. }\end{array}$} & Parent & 4.44 & 0.62 & 13.96 & & & \\
\hline & & Teac & 4.66 & 0.58 & 12.45 & -2.01 & & 0.006 \\
\hline 8 & contacts narents for academic nurnoses & & & & .09 & 2 & & 0003 > \\
\hline & & Teacher & 4.34 & 0.64 & 14.76 & 2.44 & \pm 1.99 & 0.003 \\
\hline & Discusses the examination results & Parent & 4.00 & 0.66 & 16.50 & 463 & & 0000 \\
\hline & Discusses the examination results. & Teacher & 4.56 & 0.54 & 11.84 & & & 0.000 \\
\hline 10 & & Parent & 4.19 & 0.57 & 13.60 & & & 002 \\
\hline & & Teacher & 4.30 & 0.59 & 13.72 & & & 0.002 \\
\hline & contacts parents & Parent & 3.89 & 0.63 & 16.19 & & +1 & 0001 \\
\hline & absenteeism & Teacher & 4.01 & 0.6 & & 2.67 & & \\
\hline & Discusses the nerformance of teachers & Parent & 4.17 & 0.65 & 15.59 & & $+1 c^{2} \rightarrow C_{0}$ & 0.000 \\
\hline & & Teacher & 4.33 & 0.59 & 13.63 & & & \\
\hline
\end{tabular}

The above table reflects the perception of non-SMC members who are also part of the community and have a keen interest in the affairs of schools as their children are studying there or they perform in these educational institutions. The mean values of both the respondents (teacher and parent) range from 1 to 5 and their responses reflect that under all items mean values are above the average i.e 2.5 which elucidates that as per the perception of this group the community has a higher participation rate in the affairs of schools. Since p values range from (0.000 to 0.009) which are less than 0.05 reflects that there is a significant difference in the perception of both respondents but strongly in favor of community participation. Similarly, the coefficient of variation ranges from 11.84 to 24.36 which displays the less dispersion rate.

Table 7: Comparison stakeholders regarding the participation of the community in the teaching-learning process

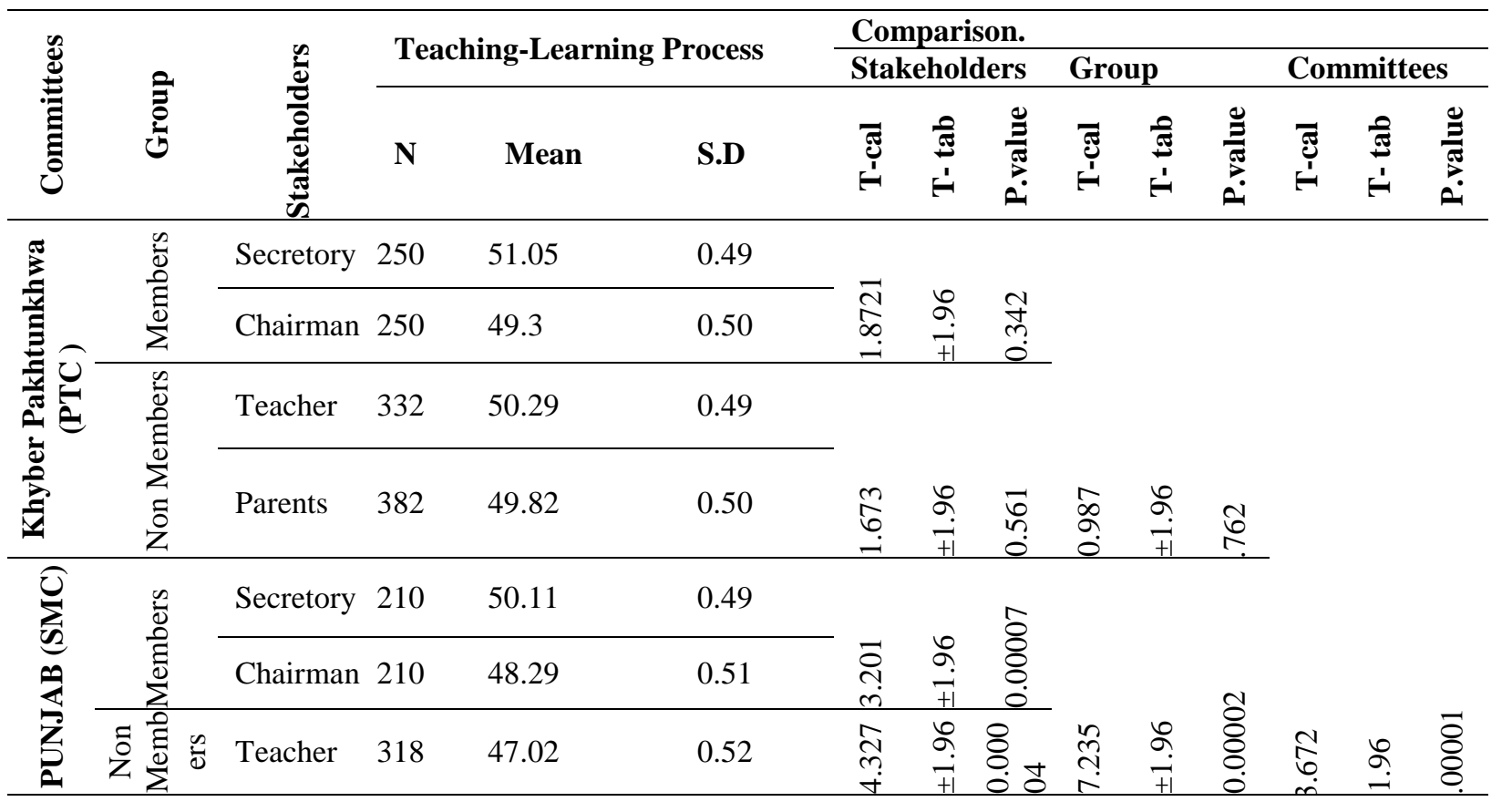




$\begin{array}{llll}\text { Parents } & 382 & 50.18 & 0.49\end{array}$

Table 04.65 reflects the comparison of the perception of stakeholders regarding the participation of community through PTCs/SMCs in the teaching-learning process, in the comparison of stakeholders of Khyber Pakhtunkhwa, the mean scores of all four stakeholders are 51.05, 49.3, 50.29, and 49.82 which are above the half i.e. 30 which show the strong participation rate of community in the affairs of school especially in the teaching-learning process. In the comparison of a group of the member of PTC t-calculated is 1.8721 which falls in the acceptance region and show that there is no significant difference in the perception of secretary and chairman of PTC committee, $t$-calculated of non-members of PTC committee is 1.673 which also falls in acceptance region and show no significant difference in the perception of teachers and parents. In the comparison of two groups, i.e. PTC (Member, Non-members) t-calculated is 0.987 which also reflects no significant difference between their viewpoints.

On the other hand in the comparison of stakeholders of Punjab, the mean score of all four stakeholders are 50.11, 48.29, 47.02, and 50.18 which are above half i.e. 30 which show the strong participation rate of the community in the affairs of the school, especially in the teaching-learning process. In a comparison of a group of a member of SMC $\mathrm{t}$-calculated is 3.201 which falls in the rejection region and show that there is a significant difference in the perception of secretary and chairman of SMC committee, t-calculated of non-members of SMC committee is 4.327 which also falls in Rejection region and show a significant difference in the perception of teachers and parents. In a comparison of two groups, i.e. SMC (Member, Non-members) t-calculated is 7.235 which also reflects the significant difference between their viewpoints.

In overall comparison between the two provinces, all the stakeholders are in favor of community participation in the teaching-learning process but a significant difference found between their perceptions as $t$-calculated value is -3.672 with a p-value of 0.00001 .

\section{DISCUSSION}

It is revealed from the present study that parents are more focused on their children's education and show their involvement in different activities of the school as described by Sequeira (2012). The progress of educational institutions may be enhanced if some willing parents take interest in motivating other parents regarding admission of students in school, creating the school environment more attractive for other children. (Garcia, 2014)

School committees sensitize the teachers about different issues faced during the teaching-learning process. They work to improve the attendance rate of students as well as teachers. Through the joint meeting, these committees try to lessen the educational problems faced by schools and teachers. (Alexander, 2009), (Andrabi, 2007)

It is clear from the findings of this study, which is supported by other studies that parents' participation in the teachinglearning process causes the improvement in the overall development of the educational institution. Students get progress when they feel that their parents are supportive and happy from their activities done in the schools. (Thill,2017) (Kwatubana \& Makhalemele, 2015)

\section{CONCLUSION}

Sketching from the results reflected in tables, it can be easily concluded that a strong rate of participation of the community is found in teaching-learning activity performed in the schools of Khyber Pakhtunkhwa as well as in Punjab. However, this rate is found stronger in Khyber Pakhtunkhwa as compared to Punjab.

From the analysis of the perception of all stakeholders of Khyber Pakhtunkhwa, Secretary of PTC committee, who is head of the institute too and teacher of the school, who is also Government employee show more interest in the affairs of school especially in the process of teaching and learning. While other two stakeholders i.e. Chairman and Parent who are not an employee of school show less interest then former pair of stakeholders.

In the province of Punjab, a slightly different situation is seen. Two stakeholders who are not employees of that institute show a higher participation ratio. So it can easily be judged that the awareness and interest level of the community in Punjab province is stronger and people are greatly concerned about their affairs of the school.

\section{RECOMMENDATIONS}

After discussing the different aspects, it has been recommended that

1. Special follow-up sessions are required to aware the Government staff working in the province of Punjab

2. Special attention is required to provide more awareness to enhance the participation rate from the community.

3. Strong documentary policy implementation strategies are required to maintain close liaison with the community members especially those whose children are in that school. 


\section{LIMITATIONS}

This study is limited to the only primary male school of two provinces of Pakistan, which may be extended to female and secondary schools in future research.

\section{AUTHORS CONTRIBUTION}

This research study is self-financed and no organization remains supportive of finance. This research is the basic idea of Dr. Abdul Hafeez and Dr. Malik Amer Atta. The designing of objective introduction hypotheses, research questions, and basic variables by both the authors. Dr. Khalid Saeed Akbar contributed to the research study in the preparation and validation of the research tool. Miss Sobia Tabassum contributed to the collection of data and analysis of data. Komal Mehreen contributed to the proofreading, citation, and revision of this article. All the team remained involved during the whole process of research.

\section{REFERENCES}

1. Alexander et al. (2009). What is learning anyway? A topographical perspective is considered. Educational psychologist, 44(3), 176-192. https://doi.org/10.1080/00461520903029006

2. Andrabi et al. (2007). Learning and Educational Achievements in Punjab Schools (LEAPS): Insights to inform the education policy debate. World Bank, Washington, DC. https://scholar.google.com/citations?view_op citation\&hl=en\&user=MB5kq1UAAAAJ\&cstart=20\&pagesize=80\&citation_for_view=MB5kq1UAAAAJ: F xGoFyzp5QC

3. Annunziata et al. (2006). Family functioning and school success in at-risk, inner-city adolescents. Journal of youth and adolescence, 35(1), 100-108. https://doi.org/10.1007/s10964-005-9016-3

4. Bryan, J. B. (2005). Fostering educational resilience and achievement in urban schools through school-familycommunity partnerships. Professional School of Counseling, 8, 219-227. https://www.jstor.org/stable/42732462

5. Child Trends (2018). Parental Involvement in Schools. Retrieved from childtrends.org: https://www.childtrends. org/?indicators=parental-involvement-in-schools.

6. Clinton, J. \& Hattie, J. (2013). New Zealand students' perceptions of parental involvement in learning and schooling: Asia Pacific Journal of Education, 33(3), 324-337. https://doi.org/10.1080/02188791.2013.786679

7. Fenton et al. (2017). The power of engagement: Sociocultural considerations in the quest for equity. Theory Into Practice, 56, 214-225. https://doi.org/10.1080/00405841.2017.1355686

8. García, L. E., \& Thornton, O. (2014). The enduring importance of parental involvement. NEA Today. https://www.region10.org/r10website/assets/File/The\%20Enduring\%20Importance\%20of\%20ParentalInvolvem $\underline{\text { en1.pdf }}$

9. Golding, K. S. (2008). Nurturing attachments. Supporting children who are fostered or adopted. Jessica Kingsley Publishers. https://books.google.com.pk/books?hl=en\&lr=\&id=dgUQBQAAQBAJ\&oi=fnd

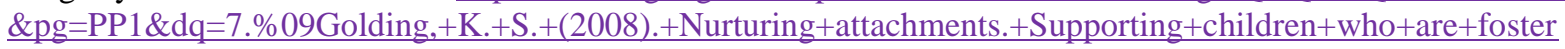
ed+or+adopted.+Jessica+Kingsley+Publishers\&ots=MKGUoQgRPG\&sig=5yVXXfRqFzXL8Y-6FL_SAv C6X50\&redir esc $=\mathrm{y} \# \mathrm{v}=$ onepage\&q\&f$=$ false

10. Government of Khyber Pakhtunkhwa, (2012). Elementary Education Foundation. Retrieved on February 25, 2012, from www.eef.org.pk/

11. Government of Khyber Pakhtunkhwa, (2017-18), Annual Statistical Report Government Schools, Education Management Information System (EMIS) Elementary \& Secondary Education Department Khyber Pakhtunkhwa Peshawar. https://kpese.gov.pk/

12. Government of Khyber Pakhtunkhwa. (2011). PTC Guide. Schools \& Literacy Department, August 2011. https://kpese.gov.pk/

13. Government of Punjab (2013). Revised School Council Policy 2007 for Government Masjid. Maktab, Primary and Middle School. (Urdu) Lahore: Punjab Education Sector Reform Programme (PESRP). https://punj ab.gov.pkl

14. Govinda, R., \& Diwan, R. (2002). Community participation and empowerment in primary education. Sage Publications India Pvt Ltd. Sage Publications India Pvt Ltd. https://www.cabdirect.org/c abdirect/abstract/20033102967

15. Habib. Z. (2014). Role of School Council in the Performance of Primary Level Students. Pakistan Journal of Commerce and Social Sciences, 8(1), 24-29.

16. Kocayörük, E., \& Şimşek, Ö. F. (2016). Parental attachment and adolescents' perception of school alienation: the mediation role of self-esteem and adjustment. The Journal of Psychology, 150(4), 405-421. https://doi.org/10.1080/00223980.2015.1060185

17. Krejcie, R. V., \& Morgan, D. W. (1970). Determining sample size for research activities. Educational and psychological measurement, 30(3), 607-610. https://doi.org/10.1177/001316447003000308

18. Kwatubana, S. \& Makhalemele, T. (2015). Parental involvement in the process of implementation of the National School Nutrition Programme in Public Schools. International Journal of Educational Sciences, 9(3), 315-323. https://doi.org/10.1080/09751122.2015.11890321

19. Lomasontfo et al. (2017). The use of corporal punishment and its effects on students' academic performance in 
Swaziland. IOSR Journal of Humanities and Social Science (IOSR-JHSS), 22(12), 53-61.

20. Nasira. H. (2010). Situation Analysis of School Councils in Five Districts of Punjab. Action Aid, Pakistan. https://eric.ed.gov/?id=EJ1210128

21. OECD. (2019). TALIS 2018 Results (Volume I) Teachers and School Leaders as Lifelong Learners. OECD Publishing.

22. Rana, M. A. (2014). Education reform in Punjab: a decentralized governance framework for government schools.

23. Sanders, M. G., \& Sheldon, S. B. (Eds.). (2009). Principals matter: A guide to school, family, and community partnerships. Corwin Press.

24. Sequeira, A. H. (2012). Introduction to concepts of teaching and learning. Available at SSRN 2150166. https://doi.org/10.2139/ssrn.2150166

25. Sikio, et al. (2017) Maternal parenting styles, homework help, and children's literacy development in language minority and Finnish-speaking families. European Journal of Psychology of Education, 33(2), 235-250. https://doi.org/10.1007/s10212-017-0330-4

26. Smith, M. K. (2006). Community participation. The encyclopedia of informal education. 2006.

27. Thill, R. F. (2017). How parental involvement benefits kids. https://www.verywellfamily.com/how-parentinvolvement-benefits-kids-3288064 